\title{
Milk quality, coagulation properties, and curd firmness modeling of purebred Holsteins and first- and second-generation crossbred cows from Swedish Red, Montbéliarde, and Brown Swiss bulls
}

\author{
F. Malchiodi, A. Cecchinato, ${ }^{1}$ M. Penasa, C. Cipolat-Gotet, and G. Bittante \\ Department of Agronomy, Food, Natural Resources, Animals and Environment (DAFNAE), University of Padova, Viale dell'Università 16, \\ 35020 Legnaro, Italy
}

\begin{abstract}
The objective of the present study was to investigate how the crossbreeding of Holstein (HO) cows with bulls from Nordic and Alpine European breeds affect milk quality traits, traditional milk coagulation properties (MCP), and curd firmness modeling obtained from individual milk samples. A total of 506 individual milk samples were collected from evening milking at $3 \mathrm{com}-$ mercial farms located in Northern Italy. Over the past decade, the 3 farms have followed crossbreeding programs in part of their herds, whereas the remainder of the animals consisted of purebred HO. The basic scheme was a 3-breed rotation based on the use of Swedish Red $(\mathrm{SR})$ semen on $\mathrm{HO}$ cows $(\mathrm{SR} \times \mathrm{HO})$, the use of Montbéliarde $(\mathrm{MO})$ semen on first-cross cows $[\mathrm{MO} \times(\mathrm{SR}$ $\times \mathrm{HO})]$, and the use of $\mathrm{HO}$ semen in the third cross. In all herds, a smaller proportion of purebred $\mathrm{HO}$ were mated to $\mathrm{M}$ and Brown Swiss (BS) bulls, and these first crosses were mated to SR and MO bulls, respectively. Milk samples were analyzed for milk composition and $\mathrm{MCP}$, and parameters for curd firmness were modeled. Compared with purebred HO, crossbred cows produced less milk with lower lactose content, higher fat and protein content, and a tendency for higher casein content. Crossbred cows generally produced milk with a more favorable curd-firming rate $\left(k_{20}\right)$ and curd firmness 30 min after rennet addition, among traditional MCP, and better trends of curd firmness measures as shown by model parameters: estimated rennet coagulation time, asymptotical potential value of curd firmness, and curd-firming instant rate constant. Among crossbred cows, SR $\times$ HO presented longer rennet coagulation time compared with $\mathrm{MO} \times \mathrm{HO}$ and $\mathrm{BS} \times \mathrm{HO}$ cows, and $\mathrm{MO} \times \mathrm{HO}$ showed shorter $\mathrm{k}_{20}$ compared with $\mathrm{BS} \times$ HO cows. Among second-generation cows, those sired by SR bulls showed a lower incidence of noncoagulated samples, higher curd firmness 30 min after rennet addi-
\end{abstract}

Received December 23, 2013.

Accepted March 20, 2014

${ }^{1}$ Corresponding author: alessio.cecchinato@unipd.it tion and asymptotical potential value of curd firmness, and faster curd-firming instant rate constant compared with animals sired by MO bulls. Our results revealed that different sire breeds were characterized by specific technological aptitudes, but that these were not strictly related to other milk quality traits. Furthermore, the favorable characteristics (in terms of the quality and technological properties of milk) could be maintained in the third generation of 3-way crosses without negative effects on milk yield, even though the $\mathrm{HO}$ heritage had been reduced from 50 to $25 \%$. Our findings, therefore, suggest that different types of sires can be chosen (depending on the intended use of the milk) to ensure the optimization of farm crossbreeding programs.

Key words: crossbreeding, milk coagulation, curd firming, Montbéliarde, Swedish Red

\section{INTRODUCTION}

Crossbreeding programs in dairy cattle are a viable strategy in the milk industry, as they may alleviate the fertility and longevity problems that can occur as a result of selection programs in dairy breeds (Heins and Hansen, 2012). However, questions have been raised regarding the need for information on optimum breed utilization (McAllister, 2002). Weigel and Barlass (2003) performed a comprehensive analysis of US dairy producers that were using crossbreeding programs. Most respondents cited the need to improve cow fertility, health, and survival as the reasons for their interest in crossbreeding. Many also emphasized the need to improve the milk fat and protein contents.

The milk production and milk quality of crossbred cows has been extensively characterized (Heins et al., 2006; Dechow et al., 2007; Prendiville et al., 2010). When compared with pure Holstein (HO) cows, crossbred cows are generally characterized for producing lower quantities of milk, fat, and protein $(\mathrm{kg})$, with higher concentrations of milk fat and protein (\%). However, the extent of these differences may vary by the crossbreed type. Heins et al. (2006) evaluated the milk yield and milk quality of first-lactation Scandinavian 
Red $\times$ HO, Montbéliarde $(\mathbf{M O}) \times \mathrm{HO}$, and Normande $\times$ HO crossbreds compared with purebred HO. The authors reported higher yields of milk, fat, and protein for purebred HO versus the crossbreds, except for Scandinavian Red $\times \mathrm{HO}$, in which no significant difference was observed for fat and protein + fat yields compared with pure HO cows. In another study, Blöttner et al. (2011) reported no difference between Brown Swiss $(\mathbf{B S}) \times \mathrm{HO}$ crossbreeds cows and purebred HO cows with respect to the protein and fat yields over the first 3 lactations. The effect of crossbreeding on dairy cows have also been analyzed across different environmental conditions (Penasa et al., 2010b; Kargo et al., 2012; Vance et al., 2012).

As reported by the International Dairy Federation (2012), the marketing of cheese has grown in recent years, and cheese plays an important role in the economics of dairy production. Some technological properties of milk are particularly important for producing traditional cheeses according to the Protected Designation of Origin (PDO) designated by the European Union. The strict definitions of the processing techniques and conditions that may be used to produce PDO cheese do not allow the use of modern technology to overcome inadequacies in the characteristics of the utilized milk; thus, top-quality milk, from a technological point of view, must be guaranteed (Martin et al., 2003; Saccà et al., 2003; Malacarne et al., 2006), also because, in the case of hard, long-ripened PDO cheeses, such as Grana Padano, Trentingrana, and Parmigiano-Reggiano, milk technological characteristics affect the quality and sensory properties of the product and are included in the milk-pricing scheme (Summer et al., 2003; Bittante et al., 2011a,b). The technological properties of individual milk samples have traditionally been analyzed through the assessment of milk coagulation properties (MCP; Annibaldi et al., 1977; McMahon and Brown, 1984) and, recently, through model cheese production (Bittante et al., 2013a; Cipolat-Gotet et al., 2013; Ferragina et al., 2013). The most commonly analyzed MCP are coagulation time and curd firmness ( $\mathbf{C F}$ ), which are obtained during the 30-min period after the addition of the enzyme (rennet) to milk. These parameters are not available for milk samples that do not coagulate by the time the analysis is finalized, making MCP less useful when the incidence of noncoagulating (NC) milk is significant. This often happens with milk from Holstein-Friesian cows and some North European breeds (Ikonen et al., 1999), which are often used in crossbreeding schemes. The presence of NC milk is not only a problem in the dairy industry; it is also an issue for researchers, because it can cause biased estimations of phenotypic or genetic parameters if proper statistical models are not used (Ikonen et al., 1999; Cecchinato and Carnier, 2011; Cecchinato, 2013). Recent studies (Cipolat-Gotet et al., 2012; Cecchinato et al., 2013) in which the lactodynamographic test was prolonged to 90 min after rennet addition demonstrated that all samples coagulated, and the so called NC samples should more properly be defined as very late-coagulating samples. To overcome these limitations, it was recently suggested that researchers should prolong the lactodynamographic test and model all of the point observations collected during the analysis for each individual sample (Bittante et al., 2012).

Milk coagulation properties are influenced by various environmental and genetic factors. Among the genetic factors, the MCP of ruminants are most strongly influenced by the animal species, with the animal breed as the second-most-influential factor. Some breeds of central southern Europe, especially the Alpine region, generally show better MCP than those originating in northern Europe (Bittante et al., 2012). However, although the effects of various breeds on MCP have been well characterized, the effects of crossbreeding have not yet been properly addressed, especially when milk is destined to PDO hard cheeses, such as Grana Padano and Parmigiano-Reggiano. In a feeding experiment, Kreuzer et al. (1996) compared Jersey $\times$ HO crossbred cows with the corresponding pure parental breeds, and found that the MCP of crossbreds were more similar to those of Jersey milk compared with HO milk. However, the studied crossbred cows all came from a Finnish Ayrshire and HO dam or sire and an unknown second parent, limiting the authors' ability to make inferences with respect to specific crossbreeds. Therefore, the aim of this study was to investigate the effect of crossbreeding $\mathrm{HO}$ cows with bulls from Nordic and Alpine European breeds on milk quality traits, traditional $\mathrm{MCP}$, and $\mathrm{CF}$ equation parameters modeled from individual milk samples produced in an intensive dairy farming system directed to the production of PDO hard, long-ripening cheese.

\section{MATERIALS AND METHODS}

\section{Milk Sampling}

Individual milk samples $(\mathrm{n}=506)$ were collected from the evening milkings of 3 commercial farms located in the province of Modena (Northern Italy) between February and March of 2013 (2 to 3 sampling days per herd). All herds were managed according to the rules for producing the PDO hard, long-ripening cheese Parmigiano-Reggiano and, thus, had similar management conditions: silage, pasture, and fresh herbage were not allowed, and the rations (fed as a TMR) were based on dry roughage, concentrates, and added water. In total, 506 individual milk samples (100 mL each) were col- 
lected. Over the past decade, the 3 farms have followed programs in which parts of their herds were crossbred, whereas the remainder consisted of purebred HO. The basic scheme was a 3-breed rotation based on the use of Swedish Red $(\mathbf{S R})$ semen on $\mathrm{HO}$ cows $(\mathrm{SR} \times \mathrm{HO})$, the use of MO semen on first-cross cows $[\mathrm{MO} \times(\mathrm{SR} \times$ $\mathrm{HO})$ ], and the use of $\mathrm{HO}$ semen in the third-generation crosses (Genesi Project Srl, Genoa, Italy). In all herds, a smaller number of purebred $\mathrm{HO}$ cows were mated to $\mathrm{MO}$ and BS bulls, and these first crosses were mated to SR and MO bulls, respectively (Figure 1). After collection, milk samples (without preservative) were refrigerated $\left(4^{\circ} \mathrm{C}\right)$ and taken to the Cheese-Making Laboratory of the Department of Agronomy, Food, Natural Resources, Animals and Environment (DAFNAE) at the University of Padova (Padova, Italy) for analysis. All samples were processed within $24 \mathrm{~h}$ of collection.

\section{Analysis of Milk Quality Traits}

Individual milk subsamples were analyzed for fat, protein, casein, and lactose contents using a MilkoScan FT2 (Foss Electric A/S, Hillerød, Denmark). Somatic cell count was obtained from a Fossomatic FC counter (Foss Electric A/S) and logarithmically transformed to SCS according to the formula proposed by Ali and Shook (1980): SCS $=3+\log _{2}(\mathrm{SCC} / 100,000)$. Milk pH was recorded using a Crison Basic 25 electrode (Crison Instruments SA, Barcelona, Spain).

\section{Analysis of MCP}

Milk coagulation properties were obtained using 2 mechanical lactodynamographs (Formagraph; Foss Electric A/S) and analyzed in duplicate for each cow. These subsamples $\left(10 \mathrm{~mL}\right.$ each) were heated to $35^{\circ} \mathrm{C}$ for $30 \mathrm{~min}$ and mixed with $200 \mu \mathrm{L}$ of a $1.2 \%$ (wt/vol) rennet solution (Hansen Standard 215, $215 \mathrm{IMCU} / \mathrm{mL}$; with $80 \pm 5 \%$ chymosin and $20 \pm 5 \%$ pepsin; Pacovis Amrein AG, Bern, Switzerland) diluted in distilled water (to yield $0.051 \mathrm{IMCU} / \mathrm{mL}$ ). The milk subsamples were then fitted into racks with 10 cuvettes each. The observation period lasted $60 \mathrm{~min}$, starting right after rennet addition. The instrument recorded the width $(\mathrm{mm})$ of the oscillatory graph every $15 \mathrm{~s}$ during testing and directly provided the traditional MCP traits: rennet coagulation time (RCT; min), defined as the time from enzyme addition to gelation of the milk; curd-firming rate $\left(\mathbf{k}_{20} ; \mathrm{min}\right)$, defined as the time from gelation to the time at which the width of the graph attained $20 \mathrm{~mm}$; and the width of the graph at $30 \mathrm{~min}$ $\left(\mathbf{a}_{30} ; \mathrm{mm}\right)$ and $45 \mathrm{~min}\left(\mathbf{a}_{\mathbf{4 5}} ; \mathrm{mm}\right)$ after rennet addition, which is a measure of the extent of CF.

\section{Modeling the CF of Individual Milk Samples}

Curd firmness was measured every $15 \mathrm{~s}$ for $60 \mathrm{~min}$, for a total of 240 recorded $\mathrm{CF}$ values per subsample. The equations proposed by Bittante et al. (2013b) for modeling of $\mathrm{CF}$ were used to analyze the data. The first equation represents a basic 3-parameter asymptotic model used to describe a CF track obtained after 30 min of analysis, and was previously explained in detail by Bittante (2011). The second equation is an extended 4-parameter model intended to describe a 90min track. We tested both models because our analysis was performed over $60 \mathrm{~min}$. The performance of the models was evaluated based on convergence and the standard errors estimated for the individual equation parameters. The 3-parameter model was chosen, as it provided higher convergence values than the 4-parameter model. The 3-parameter model is given as follows:

Purebred:

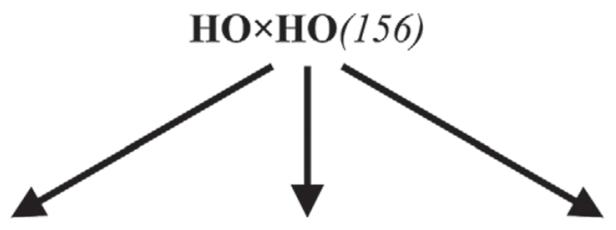

First cross:

MO $\times \mathbf{H O}(38)$

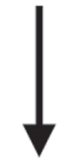

Second cross:
$\mathbf{S R} \times$ MOHO(23)
$\mathbf{S R} \times \mathbf{H O}(146)$

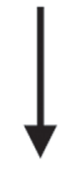

MO $\times$ SRHO(97)
$\mathbf{B S} \times \mathbf{H O}(18)$

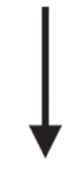

MO $\times$ BSHO (30)

Figure 1. Crossbreeding scheme and, within parentheses, the number of cows sampled for milk quality, coagulation traits, and individual curd firmness modeling analyses. $\mathrm{HO}=$ Holstein; $\mathrm{MO}=$ Montbéliarde; SR = Swedish Red; BS = Brown Swiss. 


$$
\mathrm{CF}_{t}=\mathrm{CF}_{P} \times\left(1-e^{-\mathrm{k}_{\mathrm{CF}} \times\left(t-\mathrm{RCT}_{\mathrm{eq}}\right)}\right) \text {, }
$$

where $\mathrm{CF}_{t}$ is the $\mathrm{CF}$ at time $t(\mathrm{~mm}), \mathrm{CF}_{P}$ is the asymptotical potential maximum value of $\mathrm{CF}(\mathrm{mm}), \mathbf{k}_{\mathrm{CF}}$ is the curd-firming instant rate constant $(\% / \mathrm{min})$, and $\mathbf{R C} \mathbf{T}_{\text {eq }}$ is the estimated RCT (min). This model uses all available information to estimate the 3 parameters, so that these are not single-point measurements as those achievable with traditional MCP. The $\mathrm{CF}_{t}$ observations available for each subsample were fitted with curvilinear regressions using the nonlinear procedure (PROC NLIN) of SAS (SAS Institute Inc., Cary, NC). The parameters of each individual equation were estimated by using the Marquardt iterative method (350 iterations and a $10^{-5}$ level of convergence). In some cases (often late-coagulating subsamples), the data failed to converge ( 7 of 1,012 subsamples).

\section{Statistical Analysis}

Some subsamples failed to coagulate by the end of the analysis (17 out of 1,012 subsamples) and were, thus, considered to be missing for all parameters, and called NC samples. Similarly, $\mathrm{a}_{30}$ and $\mathrm{a}_{45}$ were considered to be missing if a subsample did not coagulate after 30 or $45 \mathrm{~min}$, respectively, from the start of the analysis. Subsamples that needed more than 50 min to achieve coagulation were considered as NC (16 out of 1,012 subsamples). Subsamples that failed to converge were considered to be missing for all modeled parameters. Subsamples that met the convergence criterion but did not coagulate within $50 \mathrm{~min}$ (10 out of 1,012 subsamples) were treated as nonconverging and were excluded from further analysis, because late coagulation caused problems with the estimations of $\mathrm{CF}_{P}$ and $\mathrm{k}_{\mathrm{CF}}$. The traditional MCP data and CF modeling parameters were analyzed using PROC MIXED of SAS with the following linear model:

$$
\begin{aligned}
\mathrm{y}_{i j k l m n o}= & \mu+\mathrm{HTD}_{i}+\mathrm{DIM}_{j}+\text { Parity }_{k}+\text { Breed }_{l} \\
& + \text { Cow }_{m}+\text { Pendulum }_{n}+\mathrm{e}_{i j k l m n o},
\end{aligned}
$$

where $\mathrm{y}_{i j k l m n o}$ is the dependent variable; $\mu$ is the overall mean; $\mathrm{HTD}_{i}$ is the fixed effect of the $i$ th herd test day (HTD; $i=1$ to 7 ); $\mathrm{DIM}_{j}$ is the fixed effect of the $j$ th class of DIM $(j=1$ to 5 ; class $1:<60 \mathrm{~d}$; class $2: 60$ to $120 \mathrm{~d}$; class 3: 121 to $180 \mathrm{~d}$; class 4: 181 to $240 \mathrm{~d}$; class 5: $>240 \mathrm{~d}$ ); Parity $_{k}$ is the fixed effect of the $k$ th parity ( $k=1$ to 3 and more); Breed $_{l}$ is the fixed effect of the lth breed combination ( $l=1$ to 7 ); $\mathrm{Cow}_{m}$ is the random effect of the $m$ th cow ( $m=1$ to 506); Pendulum ${ }_{n}$ is the fixed effect of the $n$th pendulum ( $n=1$ to 20$)$; and $\mathrm{e}_{i j k l m n o}$ is the random residual. Cow and residuals were assumed to be independently and normally distributed with mean zero and variance $\sigma_{\text {cow }}^{2}$ and $\sigma_{\mathrm{e}}^{2}$, respectively, and REML was used as the method of estimation of variance components.

Analysis of variance was performed on milk yield, milk quality traits, SCS, and pH, using PROC GLM of SAS. The linear model included the fixed effects of HTD, DIM ( 5 classes of $60 \mathrm{~d}$ ), and parity and breed combination.

Orthogonal contrasts were estimated between least squares means of traits for the effects of DIM: (1) linear component and (2) quadratic component. Orthogonal contrasts were estimated between least squares means of traits for the effects of parity: (1) first-lactation versus second-lactation and third-or-more-lactation cows and (2) second-lactation versus third-or-more-lactation cows. Finally, orthogonal contrasts were estimated between least squares means of traits for the effects of breed combination: (1) the effect of crossbreeding (HO vs. all crossbred cows), (2) the effect of generation (first-cross vs. second-cross cows), (3) the effect of a Nordic sire in the first cross $(\mathrm{SR} \times \mathrm{HO}$ vs. $\mathrm{MO} \times \mathrm{HO}$ $+\mathrm{BS} \times \mathrm{HO}),(4)$ the effect of an Alpine sire in the first cross $(\mathrm{M} \times \mathrm{H}$ vs. $\mathrm{B} \times \mathrm{H}),(5)$ the effect of a Nordic sire in the second cross $(\mathrm{SR} \times \mathrm{MOHO}$ vs. $\mathrm{MO} \times \mathrm{SRHO}$ $+\mathrm{MO} \times \mathrm{BSHO}$ ), and (6) the effect of the maternal grand-sire in second-cross cows with an Alpine sire $(\mathrm{MO} \times \mathrm{SRHO}$ vs. $\mathrm{MO} \times \mathrm{BSHO})$.

\section{RESULTS}

\section{Descriptive Statistics and Sources of Variation for Milk Traits}

Descriptive statistics of milk quality traits are summarized in Table 1. On average, cows produced 31.8 $\mathrm{kg}$ of milk/d, containing $4.09 \%$ fat, $3.71 \%$ protein, and $2.71 \%$ casein. The mean values of SCS and lactose were 2.56 and $5.00 \%$, respectively. The observed coefficients of variation were high for SCS (72\%), intermediate for milk yield (31\%) and fat content (21\%), and low (less than $10 \%$ ) for all of the other quality traits.

Regarding samples, $1.7 \%$ failed to coagulate within 60 min after rennet addition, and $12.1 \%$ failed to coagulate within 30 min of analysis (late-coagulating milk samples). On average (including samples that coagulated after $30 \mathrm{~min}$ ), coagulation occurred at $20.86 \mathrm{~min}$ after rennet addition, with a $\mathrm{k}_{20}$ of $4.87 \mathrm{~min}$, and $\mathrm{a}_{30}$ and $\mathrm{a}_{45}$ were 34.44 and $44.60 \mathrm{~mm}$, respectively (Table 1). Coefficients of variation for MCP ranged from $28 \%$ $\left(\mathrm{a}_{45}\right)$ to $49 \%\left(\mathrm{k}_{20}\right)$. With respect to the parameters obtained from the individual equations describing $\mathrm{CF}$ 
Table 1. Descriptive statistics of milk yield, quality, coagulation traits, and parameters of curd firmness (CF) modeling $^{1}$

\begin{tabular}{|c|c|c|c|c|c|}
\hline Trait & $\mathrm{n}$ & Mean & $\mathrm{SD}$ & $\mathrm{P} 1$ & P99 \\
\hline Milk yield, kg/d & 506 & 31.82 & 9.95 & 11.78 & 55.20 \\
\hline \multicolumn{6}{|l|}{ Milk quality trait } \\
\hline Fat, $\%$ & 504 & 4.09 & 0.86 & 2.09 & 6.36 \\
\hline Protein, \% & 506 & 3.76 & 0.34 & 2.88 & 4.56 \\
\hline Casein, \% & 506 & 2.94 & 0.27 & 2.21 & 3.57 \\
\hline Lactose, \% & 504 & 5.00 & 0.27 & 4.16 & 5.46 \\
\hline SCS, units & 506 & 2.56 & 1.84 & -0.47 & 7.43 \\
\hline \multirow{2}{*}{\multicolumn{6}{|c|}{ Milk coagulation trait ${ }^{2}$}} \\
\hline & & & & & \\
\hline $\mathrm{RCT}, \min$ & 979 & $20.86^{3}$ & 6.95 & 10.45 & 45.2 \\
\hline $\mathrm{k}_{20}, \min$ & 959 & 4.87 & 2.38 & 2.00 & 13.0 \\
\hline $\mathrm{a}_{30}, \mathrm{~mm}$ & 900 & 34.44 & 14.9 & 1.12 & 61.3 \\
\hline $\mathrm{a}_{45}, \mathrm{~mm}$ & 977 & 44.6 & 12.5 & 2.68 & 64.7 \\
\hline \multicolumn{6}{|l|}{$\mathrm{CF}$ model $^{4}$} \\
\hline $\mathrm{RCT}_{\mathrm{eq}}, \min$ & 977 & 21.4 & 6.62 & 11.52 & 43.54 \\
\hline $\mathrm{CF}_{P}, \mathrm{~mm}$ & 977 & 50.4 & 8.09 & 26.94 & 67.56 \\
\hline $\mathrm{k}_{\mathrm{CF}}, \% / \min$ & 977 & 12.6 & 5.65 & 2.81 & 34.09 \\
\hline
\end{tabular}

(Table 1), $\mathrm{CF}_{P}$ averaged $50.4 \mathrm{~mm}$ and $\mathrm{k}_{\mathrm{CF}}$ averaged $12.6 \% / \mathrm{min}$, with a coefficient of variation of 16 and $45 \%$, respectively. The average estimated RCT was 21.4 min, which was similar to that obtained from the lactodynamographs.

The sources of variation included in the statistical model are shown in Table 2. Herd test day affected all of the tested milk quality traits (except for the lactose content), but was not significant for milk yield, traditional $\mathrm{MCP}$, or model parameters describing the $\mathrm{CF}$ of individual milk samples (Table 2). The stage of lactation was a major source of variation for all studied traits. Parity exerted a smaller effect than DIM; it was significant for the milk yield and quality traits (except for the fat content), but did not affect the traditional $\mathrm{MCP}$ or the $\mathrm{CF}$ parameters (except for $\mathrm{CF}_{P}$ ). The breed combination was less important than DIM and parity, but nevertheless affected most of the studied traits.

The duplicate analyses for the MCP and CF parameters allowed us to discriminate between the effects of the animals and residuals on phenotypic variability, with the prevalence of the first for all $\mathrm{MCP}$ and $\mathrm{RCT}_{\text {eq }}$, and of the second for the remaining traits (Table 2). Within each animal, the individual pendulum of the lactodynamograph exerted an effect on all traits except for $\mathrm{CF}_{P}$.

\section{Effects of Parity and DIM on Milk Traits}

Primiparous cows produced high-quality milk in lesser amounts compared with multiparous cows, and second-lactation cows had higher milk protein contents than cows with 3 or more lactations $(-0.05 \% ; P<0.05$; Table 3).

Regarding milk coagulation, the incidence of NC samples was higher for second-lactation cows than for all other cows. Among the traditional MCP, milk produced after the second calving presented an increase in $\mathrm{k}_{20}(P$ $<0.10)$, whereas for CF modeling, parity was associated with a slightly higher $\mathrm{CF}_{P}$ of second-lactation cows relative to older cows $(-1.65 \mathrm{~mm} ; P<0.05$; Table 4$)$.

In contrast, the effects of DIM were highly significant $(P<0.001)$ for all parameters that showed a linear increase during lactation, except for milk yield and lactose content (which decreased linearly), and $\mathrm{pH}$ (which showed linear and quadratic increases). The incidence of NC samples (i.e., those that failed to coagulate within $30 \mathrm{~min}$ ) increased during the first half of lactation and remained high during the second half. Furthermore, all coagulation traits and CF model parameters worsened during lactation (as reflected by increased coagulation time and $\mathrm{k}_{20}$, accompanied by decreases in $\mathrm{CF}$ and the $\mathrm{k}_{\mathrm{CF}}$ ), especially during the first half of lactation, when a quadratic pattern was seen. The exception here was $\mathrm{CF}_{P}$, which showed a slight linear decrease during lactation (Table 4).

\section{Effects of Breed Combination on Milk Traits}

Compared with purebred HO, crossbred cows produced less milk $(P<0.001)$ with lower lactose content $(P<0.01)$, higher fat and protein contents $(P<$ 0.01 and $P<0.05$, respectively), and a tendency for higher casein content $(P=0.06$; Table 5$)$. Milk from 
Table 2. Results from ANOVA ( $F$-value and significance) for milk yield, quality, coagulation traits, and individual parameters of curd firmness (CF) modeling

\begin{tabular}{|c|c|c|c|c|c|c|c|}
\hline Trait & $\mathrm{HTD}^{1}$ & DIM & Parity & Breed & Pendulum & Animal & $\mathrm{RMSE}^{2}$ \\
\hline Fat, $\%$ & $2.56^{*}$ & $8.69^{* * *}$ & $1.64^{\mathrm{NS}}$ & $3.53^{* *}$ & & & 0.81 \\
\hline Casein, $\%$ & $4.94^{* * *}$ & $51.43^{* * *}$ & $6.29^{* *}$ & $1.82 \dagger$ & & & 0.21 \\
\hline Lactose, \% & $1.78^{\mathrm{NS}}$ & $26.47^{* * *}$ & $21.26^{* * *}$ & $3.59^{* *}$ & & & 0.22 \\
\hline SCS, units & $4.75^{* * *}$ & $12.92^{* * *}$ & $6.54^{* *}$ & $1.34^{\mathrm{NS}}$ & & & 1.72 \\
\hline \multicolumn{8}{|c|}{ Milk coagulation trait ${ }^{3}$} \\
\hline $\mathrm{RCT}, \min$ & $0.83^{\mathrm{NS}}$ & $31.06^{* * *}$ & $1.31^{\mathrm{NS}}$ & $1.47^{\mathrm{NS}}$ & $3.59^{* * *}$ & 6.07 & 1.61 \\
\hline $\mathrm{k}_{20}, \min$ & $0.78^{\mathrm{NS}}$ & $5.72^{* * *}$ & $2.00^{\mathrm{NS}}$ & $2.35^{*}$ & $3.66^{* * *}$ & 2.12 & 0.97 \\
\hline $\mathrm{a}_{30}, \mathrm{~mm}$ & $0.67^{\mathrm{NS}}$ & $5.81^{* * *}$ & $1.11^{\mathrm{NS}}$ & $2.99 * *$ & $3.40^{* * *}$ & 12.38 & 7.94 \\
\hline $\mathrm{a}_{45}, \mathrm{~mm}$ & $0.40^{\mathrm{NS}}$ & $6.52^{* * *}$ & $0.75^{\mathrm{NS}}$ & $1.27^{\mathrm{NS}}$ & $1.72^{*}$ & 9.22 & 8.11 \\
\hline \multicolumn{8}{|l|}{ CF model ${ }^{4}$} \\
\hline $\mathrm{RCT}_{\mathrm{eq}}, \min$ & $0.95^{\mathrm{NS}}$ & $7.20^{* * *}$ & $1.25^{\mathrm{NS}}$ & $2.04 \dagger$ & $3.88^{* * *}$ & 5.94 & 2.54 \\
\hline $\mathrm{CF}_{P}, \mathrm{~mm}$ & $1.48^{\mathrm{NS}}$ & $3.33^{*}$ & $3.14^{*}$ & $1.65^{\mathrm{NS}}$ & $1.07^{\mathrm{NS}}$ & 0.01 & 8.03 \\
\hline
\end{tabular}

${ }^{1}$ Herd test day.

${ }^{2}$ Root mean square error.

${ }^{3} \mathrm{RCT}=$ rennet coagulation time; $\mathrm{k}_{20}=$ curd-firming rate; $\mathrm{a}_{30}=\mathrm{CF} 30$ min after rennet addition; $\mathrm{a}_{45}=\mathrm{CF} 45$ min after rennet addition.

${ }^{4} \mathrm{RCT}_{\mathrm{eq}}=$ estimated $\mathrm{RCT} ; \mathrm{CF}_{P}=$ asymptotical potential value of $\mathrm{CF} ; \mathrm{k}_{\mathrm{CF}}=$ curd-firming instant rate constant.

$\dagger P<0.10 ;{ }^{*} P<0.05 ;{ }^{* *} P<0.01 ; * * * P<0.001$.

second-generation cows exhibited higher $\mathrm{pH}$ than firstgeneration animals $(P<0.05)$, and $\mathrm{MO} \times(\mathrm{BS} \times \mathrm{HO})$ crossbred cows showed higher fat content than $\mathrm{MO} \times$ $(\mathrm{SR} \times \mathrm{HO})$ crossbreds $(+0.39 \% ; P<0.05)$. Somatic cell score was not affected by breed combination, although values tended to be lower for $\mathrm{SR} \times \mathrm{HO}$ compared with $\mathrm{MO} \times \mathrm{HO}$ and $\mathrm{BS} \times \mathrm{HO}(P=0.08)$.

The incidence of NC samples did not clearly differ between purebred $\mathrm{H}$ and crossbred cows, but the latter generally produced milk with shorter $\mathrm{k}_{20}$ and $\mathrm{RCT}_{\text {eq, }}$ and higher $\mathrm{a}_{30}, \mathrm{CF}_{P}$, and $\mathrm{k}_{\mathrm{CF}}(P<0.05$; Table 6). Among crossbred cows, SR $\times$ HO presented a higher incidence of $\mathrm{NC}$ samples and longer RCT compared with $\mathrm{MO} \times \mathrm{HO}$ and $\mathrm{BS} \times \mathrm{HO}$ animals $(P<0.05)$, and
$\mathrm{MO} \times \mathrm{HO}$ showed shorter $\mathrm{k}_{20}$ compared with $\mathrm{BS} \times$ HO cows $(P<0.05)$. Among second-generation cows, those sired by SR bulls showed a lower incidence of $\mathrm{NC}$, higher $\mathrm{a}_{30}$ and $\mathrm{CF}_{\mathrm{P}}$, and faster $\mathrm{k}_{\mathrm{CF}}$ compared with animals sired by MO bulls $(P<0.05)$.

\section{DISCUSSION}

\section{Effect of Breed Combination on Milk Yield and Quality Traits}

The design of the contrasts used in the present study allowed us to specifically compare traits of the pure HO cows versus all of the examined crossbreeds, and to

Table 3. Least squares means of milk yield and quality across parities and DIM

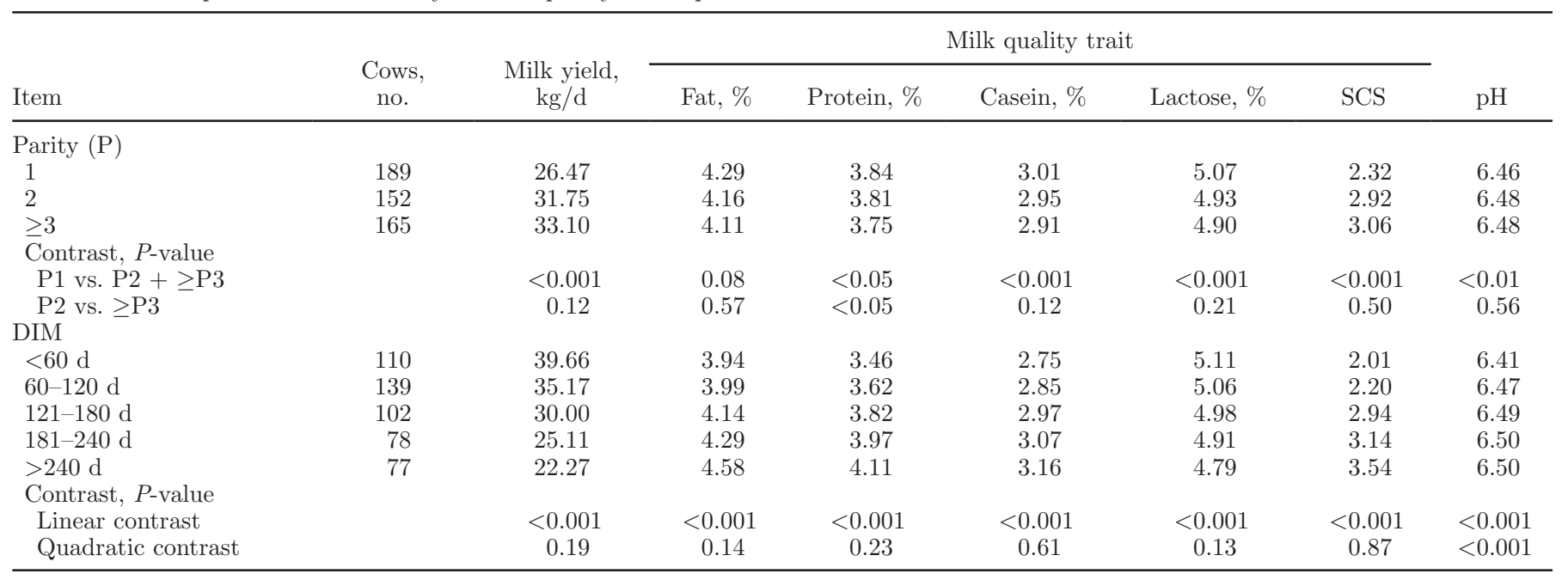


Table 4. Least squares means of milk coagulation properties measured by Formagraph (Foss Electric A/S, Hillerød, Denmark) and of estimated parameters of individual curd firmness $(\mathrm{CF})$ equations across parities and DIM

\begin{tabular}{|c|c|c|c|c|c|c|c|c|}
\hline \multirow[b]{2}{*}{ Item } & \multirow[b]{2}{*}{$\begin{array}{c}\mathrm{NC},{ }^{1} \\
\%\end{array}$} & \multicolumn{4}{|c|}{ Milk coagulation trait ${ }^{2}$} & \multicolumn{3}{|c|}{$\mathrm{CF}$ model $^{3}$} \\
\hline & & $\begin{array}{c}\mathrm{RCT}, \\
\mathrm{min}\end{array}$ & $\begin{array}{l}\mathrm{k}_{20}, \\
\min \end{array}$ & $\begin{array}{l}\mathrm{a}_{30}, \\
\min \end{array}$ & $\begin{array}{l}\mathrm{a}_{45}, \\
\min \end{array}$ & $\begin{array}{c}\mathrm{RCT}_{\mathrm{eq}} \\
\min \end{array}$ & $\begin{array}{l}\mathrm{CF}_{P}, \\
\mathrm{~mm}\end{array}$ & $\begin{array}{l}\mathrm{k}_{\mathrm{CF}}, \\
\% / \mathrm{min}\end{array}$ \\
\hline \multicolumn{9}{|l|}{ Parity (P) } \\
\hline 1 & 10.3 & 20.2 & 4.5 & 36.3 & 45.7 & 20.3 & 50.5 & 13.4 \\
\hline 2 & 17.1 & 21.3 & 5.0 & 35.5 & 45.4 & 21.3 & 51.7 & 13.2 \\
\hline$>3$ & 9.4 & 21.2 & 4.9 & 33.5 & 44.0 & 21.4 & 50.1 & 12.5 \\
\hline \multicolumn{9}{|l|}{ Contrast, $P$-value } \\
\hline P2 vs. P3 & & 0.88 & 0.74 & 0.26 & 0.30 & 0.87 & $<0.05$ & 0.26 \\
\hline \multicolumn{9}{|l|}{ DIM } \\
\hline$<60 \mathrm{~d}$ & 0.0 & 15.1 & 3.8 & 40.6 & 49.4 & 18.0 & 51.8 & 14.9 \\
\hline $60-120 \mathrm{~d}$ & 6.5 & 19.6 & 4.7 & 36.3 & 45.6 & 20.9 & 51.1 & 13.3 \\
\hline $121-180 \mathrm{~d}$ & 17.2 & 22.2 & 5.0 & 34.3 & 45.4 & 21.6 & 51.6 & 13.0 \\
\hline $181-240 \mathrm{~d}$ & 23.7 & 23.8 & 5.2 & 31.2 & 41.1 & 22.5 & 48.8 & 11.5 \\
\hline$>240 \mathrm{~d}$ & 20.8 & 23.7 & 5.2 & 33.0 & 43.7 & 21.9 & 50.6 & 12.3 \\
\hline
\end{tabular}

${ }^{1}$ Noncoagulating samples within 30 min after rennet addition.

${ }^{2} \mathrm{RCT}=$ rennet coagulation time; $\mathrm{k}_{20}=$ curd-firming rate; $\mathrm{a}_{30}=\mathrm{CF} 30$ min after rennet addition; $\mathrm{a}_{45}=\mathrm{CF} 45$ min after rennet addition.

${ }^{3} \mathrm{RCT}_{\mathrm{eq}}=$ estimated $\mathrm{RCT} ; \mathrm{CF}_{P}=$ asymptotical potential value of $\mathrm{CF} ; \mathrm{k}_{\mathrm{CF}}=$ curd-firming instant rate constant.

evaluate differences within the crossbreeds. Our results suggest that the crossbred cows were fairly similar in terms of milk yield, milk quality traits and SCS, as most of the observed variation was found when we compared pure $\mathrm{HO}$ cows with all of the crossbreeds.

This study was based on a single milk sample per cow and was not designed to study milk production, but rather to examine its technological properties for cheese making. However, the lower milk yield $(-9.1 \%)$ of crossbred cows compared with HO cows, which has generally been reported in the literature (Heins and Hansen, 2012), was also observed in the current study. In addition, crossbred cows showed higher milk fat, protein, and casein contents relative to pure HO cows $(+6.6,+1.7$, and $+1.8 \%$, respectively). Heins and Hansen (2012) reported similar results when they compared $\mathrm{MO} \times \mathrm{HO}$ and Scandinavian Red $\times \mathrm{HO}$ crossbreds with purebred $\mathrm{HO}$ cows, finding that the crossbreds

Table 5. Least squares means of milk yield and quality across breed combinations

\begin{tabular}{|c|c|c|c|c|c|c|c|c|}
\hline Item & $\begin{array}{c}\text { Cows, } \\
\text { no. }\end{array}$ & $\begin{array}{l}\text { Milk yield, } \\
\mathrm{kg} / \mathrm{d}\end{array}$ & \multicolumn{5}{|c|}{ Milk quality trait } & $\mathrm{pH}$ \\
\hline \multicolumn{9}{|l|}{ Breed $^{1}$} \\
\hline $\mathrm{HO} \times \mathrm{HO}$ & 159 & 33.02 & 3.96 & 3.74 & 2.92 & 5.03 & 2.88 & 6.47 \\
\hline \multicolumn{9}{|l|}{ First-generation crossbred } \\
\hline $\mathrm{SR} \times \mathrm{HO}$ & 140 & 29.89 & 4.34 & 3.86 & 3.00 & 4.91 & 2.35 & 6.47 \\
\hline \multicolumn{9}{|l|}{ Second-generation crossbred } \\
\hline $\mathrm{SR} \times(\mathrm{MO} \times \mathrm{HO})$ & 20 & 31.26 & 4.30 & 3.82 & 2.97 & 4.96 & 2.66 & 6.48 \\
\hline $\mathrm{MO} \times(\mathrm{SR} \times \mathrm{HO})$ & 103 & 29.24 & 3.95 & 3.81 & 2.97 & 4.97 & 2.74 & 6.50 \\
\hline $\mathrm{MO} \times(\mathrm{BS} \times \mathrm{HO})$ & 26 & 28.90 & 4.34 & 3.74 & 2.91 & 4.99 & 2.96 & 6.49 \\
\hline \multicolumn{9}{|l|}{ Contrast, $P$-value } \\
\hline Purebred vs. crossbreds & & $<0.001$ & $<0.01$ & $<0.05$ & 0.06 & $<0.01$ & 0.48 & 0.74 \\
\hline First vs. second generation & & 0.72 & 0.70 & 0.44 & 0.37 & 0.50 & 0.79 & $<0.05$ \\
\hline
\end{tabular}

${ }^{1} \mathrm{HO}=$ Holstein; $\mathrm{SR}=$ Swedish Red; MO = Montbéliarde; BS = Brown Swiss. 
Table 6. Least squares means of milk coagulation properties measured by Formagraph (Foss Electric A/S, Hillerød, Denmark) and of parameters of individual curd firmness $(\mathrm{CF})$ equations across breed combinations

\begin{tabular}{|c|c|c|c|c|c|c|c|c|}
\hline \multirow[b]{2}{*}{ Item } & \multirow[b]{2}{*}{$\begin{array}{c}\mathrm{NC},{ }^{1} \\
\%\end{array}$} & \multicolumn{4}{|c|}{ Milk coagulation trait ${ }^{2}$} & \multicolumn{3}{|c|}{$\mathrm{CF}_{\text {model }}{ }^{3}$} \\
\hline & & $\begin{array}{l}\mathrm{RCT}, \\
\text { min }\end{array}$ & $\begin{array}{l}\mathrm{k}_{20}, \\
\text { min }\end{array}$ & $\begin{array}{l}\mathrm{a}_{30} \\
\mathrm{~min}\end{array}$ & $\begin{array}{l}\mathrm{a}_{45}, \\
\mathrm{~min}\end{array}$ & $\begin{array}{c}\mathrm{RCT}_{\text {eq }} \\
\text { min }\end{array}$ & $\begin{array}{l}\mathrm{CF}_{P}, \\
\mathrm{~mm}\end{array}$ & $\begin{array}{c}\mathrm{k}_{\mathrm{CF}}, \\
\% / \mathrm{min}\end{array}$ \\
\hline \multicolumn{9}{|l|}{ Breed $^{4}$} \\
\hline \multicolumn{9}{|l|}{ Purebred } \\
\hline $\mathrm{HO} \times \mathrm{HO}$ & 11.0 & 21.4 & 5.3 & 30.4 & 43.4 & 22.4 & 49.6 & 12.1 \\
\hline \multicolumn{9}{|l|}{ First-generation crossbred } \\
\hline $\mathrm{BS} \times \mathrm{HO}$ & 12.5 & 20.1 & 5.3 & 35.9 & 44.2 & 21.3 & 51.1 & 12.0 \\
\hline \multicolumn{9}{|l|}{ Second-generation crossbred } \\
\hline $\mathrm{SR} \times(\mathrm{MO} \times \mathrm{HO})$ & 5.0 & 19.5 & 4.2 & 41.3 & 49.2 & 19.2 & 53.6 & 15.6 \\
\hline $\mathrm{MO} \times(\mathrm{SR} \times \mathrm{HO})$ & 12.1 & 22.2 & 5.0 & 33.4 & 44.1 & 21.6 & 49.8 & 12.6 \\
\hline $\mathrm{MO} \times(\mathrm{BS} \times \mathrm{HO})$ & 7.7 & 20.9 & 4.8 & 32.9 & 44.3 & 20.8 & 49.6 & 13.3 \\
\hline \multicolumn{9}{|l|}{ Contrast, $P$-value } \\
\hline Purebred vs. crossbreds & & 0.37 & $<0.05$ & $<0.001$ & 0.13 & $<0.05$ & $<0.05$ & $<0.05$ \\
\hline
\end{tabular}

\footnotetext{
${ }^{1}$ Noncoagulating samples within 30 min after rennet addition.

${ }^{2} \mathrm{RCT}=$ rennet coagulation time; $\mathrm{k}_{20}=$ curd-firming rate; $\mathrm{a}_{30}=\mathrm{CF} 30$ min after rennet addition; $\mathrm{a}_{45}=\mathrm{CF} 45$ min after rennet addition.

${ }^{3} \mathrm{RCT}_{\mathrm{eq}}=$ estimated $\mathrm{RCT} ; \mathrm{CF}_{P}=$ asymptotical potential value of $\mathrm{CF} ; \mathrm{k}_{\mathrm{CF}}=$ curd-firming instant rate constant.

${ }^{4} \mathrm{HO}=$ Holstein $; \mathrm{SR}=$ Swedish Red; $\mathrm{MO}=$ Montbéliarde; $\mathrm{BS}=$ Brown Swiss.
}

had a lower milk yield $(-6.4 \%)$, higher mean fat and protein contents $(+3.3$ and $+3.4 \%$, respectively $)$, and a slightly lower fat content and protein yield $(-3.3$ and $-3.4 \%$, respectively). Similar results have been also reported for $\mathrm{BS} \times \mathrm{HO}$ crossbred cows (Brandt et al., 1974) and $\mathrm{SR} \times \mathrm{HO}$ and second-generation $\mathrm{MO} \times(\mathrm{SR}$ $\times$ HO) crossbred cows (Malchiodi et al., 2011), compared with pure $\mathrm{HO}$.

Our finding that SCS was not significantly affected by breed composition agrees with previous studies comparing $\mathrm{BS} \times \mathrm{HO}$ crossbred cows with pure $\mathrm{HO}$ (Dechow et al., 2007; Blöttner et al., 2011). Heins and Hansen (2012) found significantly lower SCS in MO $\times$ $\mathrm{HO}$ and Scandinavian Red $\times$ HO crossbred cows compared with pure $\mathrm{HO}$, with $\mathrm{MO} \times \mathrm{HO}$ crossbred cows showing the lowest milk SCS values over the entirety of lactation, whereas the Scandinavian Red cows showed intermediate values between those of pure $\mathrm{HO}$ and $\mathrm{MO}$ $\times \mathrm{HO}$ crossbred cows. In our study, $\mathrm{SR} \times \mathrm{HO}$ crossbreds showed the lowest milk SCS values; they tended to be lower compared with those of $\mathrm{BS} \times \mathrm{HO}$ and $\mathrm{MO}$ $\times$ HO cows.

\section{Effect of HTD, Parity, and DIM on MCP and the Parameters Modeled for CF}

Although the herd and test date effects strongly affected milk quality traits, they did not influence MCP and $\mathrm{CF}$ parameters. These results are in accordance with other studies that reported a small effect of herd on the variation of MCP (Ikonen et al., 2004; Tyrisevä et al., 2004). A recent review on the genetics and modeling of MCP (Bittante et al., 2012) indicated that the herd effects of RCT and $\mathrm{a}_{30}$ accounted, on average, for only about $5 \%$ of the total variance of these traits, whereas the effects of herd varied from about 10 to $30 \%$ for other milk traits. Cipolat-Gotet et al. (2012) found that the herd had a significant effect on MCP; however, the number and heterogeneity of herds was high in their study, and the actual herd effect was similar to that of parity (and thus much smaller than that of DIM). Our study, in contrast, examined 3 herds that had similar management conditions and farm sizes, and used a very short sampling period.

Consistent with the results from other studies (Ikonen et al., 2004; Tyrisevä et al., 2004; Cipolat-Gotet et al., 2013), we found that the MCP changed during lactation (i.e., they showed a quadratic response to DIM): they exhibited rapid worsening (delayed gelation time and slowing/reduction of curd firming) during the early stage of lactation, followed by a more stable pattern, and eventually recovered somewhat during the last part of lactation. The number of NC samples also increased rapidly during the first part of lactation and then stabilized thereafter, in agreement with the findings of Tyrisevä et al. (2004). This reflects that the milk pH, which showed a significant quadratic increase during lactation, is (together with titratable acidity) highly 
correlated with MCP but opposes the trends of protein and casein, which are positively correlated with CF (Bittante et al., 2012; Macciotta et al., 2012).

Similar to previous reports (Ikonen et al., 2004; Tyrisevä et al. 2004), we found that parity did not affect MCP. Ikonen et al. (2004) reported that this only occurs when coagulated samples are analyzed, and that primiparous cows had more NC samples than multiparous cows (17 vs. 9\%, respectively). However, our present results indicate that the number of $\mathrm{NC}$ samples increased from the first to second parity and decreased in multiparous cows. Cipolat-Gotet et al. (2012) found a similar trend for RCT in BS cows, with this parameter increasing from the first to second lactations and decreasing thereafter. In that same study, the authors found $\mathrm{a}_{45}$ to decrease as parity increased, in agreement with Tyrisevä et al. (2003), who showed that MCP deteriorated as parity increased. However, the contradictory effects of parity on MCP could be explained by the use of different breeds across studies, suggesting that the effect of parity likely differs between breeds.

Comparison of the present results to those from the $\mathrm{BS}$ and $\mathrm{HO}$ milk samples used to evaluate the $\mathrm{CF}$ model (Bittante, 2011) revealed that (on average) milk from the crossbred cows examined in the present study showed a longer RCT $(19.0,20.1$, and 21.4 min for BS, $\mathrm{HO}$, and crossbred cows, respectively), a higher $\mathrm{CF}_{P}$ (43.6, 33.8, and $50.4 \mathrm{~mm}$, respectively), and an intermediate $\mathrm{k}_{\mathrm{CF}}(13.8,11.3$, and $12.6 \% / \mathrm{min}$, respectively). All of the above-mentioned samples were analyzed in the same laboratory using the same instruments and conditions (except for test length); therefore, the observed differences can be attributed to the inherent characteristics of the analyzed milk samples. As expected, $\mathrm{RCT}_{\mathrm{eq}}$ showed patterns similar to that of the single-point RCT.

Unlike the $C F$ values measured after 30 or $45 \mathrm{~min}$ after enzyme addition, $\mathrm{CF}_{P}$ showed very modest (but significant) effects of parity and DIM. This suggests that the endpoint of $\mathrm{CF}$ tended to be fairly constant across the most important individual factors, and that the differences in $\mathrm{CF}$ registered in the early phase of curd firming were mainly due to differences in the velocity of the curd-firming process. In fact, $\mathrm{k}_{\mathrm{CF}}$ was strongly affected by DIM (i.e., there was a quadratic decrease during lactation) but not by parity, which was similar to our observations for the traditional MCP.

\section{Effect of Crossbreeding and Breed Combinations on MCP and CF Model Parameters}

In general, crossbred cows showed favorable MCP values compared with pure $\mathrm{HO}$ cows, in terms of both milk coagulation traits directly measured by lactodyna- mograph and the CF parameters obtained from instrument output modeling. The milk of crossbreds showed better curd-firming values in terms of both the $\mathrm{k}_{20}$ and $\mathrm{k}_{\mathrm{CF}}$ coefficients, and $\mathrm{CF}_{P}$ and $\mathrm{a}_{30}$ were both positive for crossbred cows compared with pure HO. The RCT showed some differences when they were measured by the instrument as single-point values (not significant) and estimated by our modeling of all CF measures obtained by the lactodynamographs $\left(\mathrm{RCT}_{\text {eq }}\right.$ was improved by crossbreeding). The $\mathrm{a}_{45}$ was not significantly affected by crossbreeding. However, this could also reflect that CF peaks at later coagulation times and decreases thereafter, in a process called microsyneresis (McMahon et al., 1984). As samples that coagulate earlier could show a decrease in CF before the end of the analysis, the $\mathrm{a}_{45}$ could be similar to that of later-coagulating samples in which CF is still in the incremental phase, as demonstrated by Bittante et al. (2013b) in BS cows. We did not observe such an effect overall in the present study because our samples had a late coagulation time, on average; however, some samples showed signs of undergoing microsyneresis. The use of a $\mathrm{CF}$ model allowed us to account for this phenomenon, and $\mathrm{CF}_{P}$ was not affected by the decrease in $\mathrm{CF}$ and thus by gelation time. The MCP differences that we observed among the crossbreds could reflect differences inherent to the pure breeds represented within the crossbred cows. Bittante et al. (2012) compared various breeds based on the results from numerous studies, and found that pure BS had much more favorable MCP than pure HO. The MO breed (which was grouped with Simmental in the study) was also favorable for all the parameters compared with pure $\mathrm{HO}$, but to a slightly lesser degree than pure BS. In contrast, the Scandinavian breeds, particularly the Finnish Ayrshire, had the least favorable MCP compared with pure HO. In agreement with these results, our study suggests that BS and MO sires can improve $\mathrm{RCT}$ but do not appear to affect the curd-firming rate or $\mathrm{CF}$, as reported in previous studies on purebred BS (Malossini et al., 1996; Malacarne et al., 2006; Cecchinato et al., 2009, 2011) and MO (Macheboeuf et al., 1993). Conversely, SR is not currently considered a desirable breed for improving MCP. For example, Poulsen et al. (2013) reported that SR had a longer RCT and more NC samples relative to Danish HO, although the 2 breeds did not differ in their curd-firming rates. Here, we report that the first-generation $\mathrm{MO} \times \mathrm{HO}$ and $\mathrm{BS}$ $\times \mathrm{HO}$ crossbreds had faster coagulation times than the $\mathrm{SR} \times \mathrm{HO}$ crossbreds, whereas no significant difference in $\mathrm{CF}$ existed among these crossbreds.

The comparison becomes more complex when we also consider 3 -way crosses. Figure 2 shows that the averages of the traditional MCP for 3-way crossbred cows were more similar to those of their maternal 2-way 


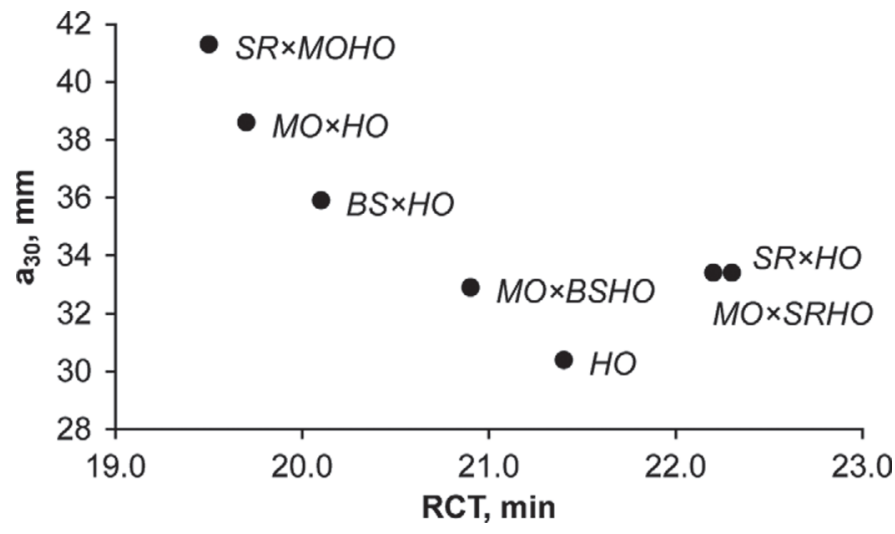

Figure 2. Least squares means for rennet coagulation time (RCT) and curd firmness $30 \mathrm{~min}$ after rennet addition to milk $\left(\mathrm{a}_{30}\right)$ across breed combinations. $\mathrm{HO}=$ Holstein; $\mathrm{SR}=$ Swedish Red; $\mathrm{MO}=$ Montbéliarde; BS = Brown Swiss.

breed combination than the 2-way combination having the same sire breed. This explains why the $\mathrm{SR} \times$ $\mathrm{HO}$ crossbreds had the longest RCT, whereas the SR $\times(\mathrm{MO} \times \mathrm{HO})$ crossbreds had the shortest RCT. A possible maternal genetic effect on MCP may also be inferred from the results of the only 2 previous studies that compared crossbred cows and the purebred cows of both parental breeds. Kreuzer et al. (1996) and Tyrisevä et al. (2004) compared Jersey $\times$ HO and $\mathrm{HO} \times$ Finnish Ayrshire crossbreds, respectively, with their parental breeds and found that the MCP of the crossbred cows were more similar to those of the Jersey and Ayrshire purebreds, respectively, than to those of purebred HO cows. Moreover, Figure 2 shows that the majority of breed combinations exhibited a strong negative correlation between RCT and $\mathrm{a}_{30}$, as is often found in the literature (Bittante et al., 2012). A clear exception to this rule, however, may be seen in the SR $\times \mathrm{HO}$ cows and their daughters $[\mathrm{MO} \times(\mathrm{SR} \times \mathrm{HO})]$, which had the longest RCT but not the lowest $\mathrm{a}_{30}$. This finding is consistent with the comparison between SR and HO purebreds reported by Poulsen et al. (2013).

Comparisons based on individual CF model parameters (Figure 3) showed that the correlation between $\mathrm{RCT}_{\mathrm{eq}}$ and $\mathrm{k}_{\mathrm{CF}}$ was broader than that observed for the traditional MCP, and the relative positions of the different breed combinations were rearranged compared with those seen in Figure 2. The estimation of the CF model parameters also allowed us to map $\mathrm{CF}$ over time for each breed combination. Pure HO cows exhibited the lowest $\mathrm{CF}$ at any time relative to the 3 first-generation crossbreds, largely due to their longer RCT. The most favorable pattern was exhibited by $\mathrm{MO} \times \mathrm{HO}$ cows, followed by $\mathrm{BS} \times \mathrm{HO}$ cows, whereas the $\mathrm{SR} \times \mathrm{HO}$ cows almost overlapped with the HO curve (Figure 4a). The second-generation crossbreds showed more favorable patterns of curd firming compared with pure $\mathrm{HO}$ cows. Among the different crosses, it is evident that the more favorable outcomes are found, not in first-generation cows from MO sires, but rather in their daughters obtained from SR bulls. This more favorable pattern is not only due to a shorter RCT, but also to a steeper $\mathrm{k}_{\mathrm{CF}}$ and a higher $\mathrm{CF}_{P}$ value.

The difference found between breed groups could also be explained by protein composition. In fact, studies on purebreds have suggested that differences in the proportion of different protein fractions (Jõudu et al., 2008), differences in the frequency of their genetic variants (Macheboeuf et al., 1993; Hallén et al., 2007), or both (Bonfatti et al., 2010) could help explain the differences in their MCP. Ikonen et al. (1999), Penasa et al. (2010a), and Bonfatti et al. (2011) evaluated pure Finnish Ayrshire, HO, and Simmental cows, respectively, and reported that an important fraction of the within-breed genetic variance of MCP depends on the genetic variants of milk proteins. Other studies have also shown that the MCP differences between $\mathrm{HO}$ and $\mathrm{MO}$ (Auldist et al., 2002) and between HO and Finnish Ayrshire (Ikonen et al., 1999) were strongly reduced after the models were adjusted for the $\mathrm{k}$-CN genotype. Therefore, further studies on milk protein profiles and the genetic variants of different protein fractions could help explain the differences found among breed groups.

\section{CONCLUSIONS}

Previous studies have shown that HO-based crossbred cows can compensate for their lower milk production by superior fertility, longevity, and milk quality. The present study also shows that crossbreeding can be a

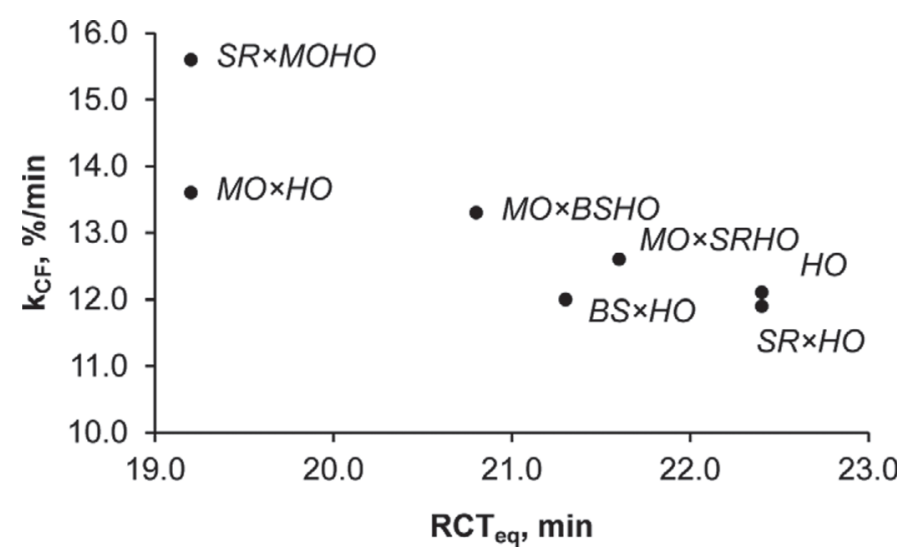

Figure 3. Least squares means for rennet coagulation time (RCT) obtained through individual modeling (estimated $\mathrm{RCT}, \mathrm{RCT}_{\mathrm{eq}}$ ) and curd-firming instant rate constant $\left(\mathrm{k}_{\mathrm{CF}}\right.$ ) of milk across breed combinations. $\mathrm{HO}=$ Holstein; $\mathrm{SR}=$ Swedish Red; $\mathrm{MO}=$ Montbéliarde; $\mathrm{BS}$ $=$ Brown Swiss. 

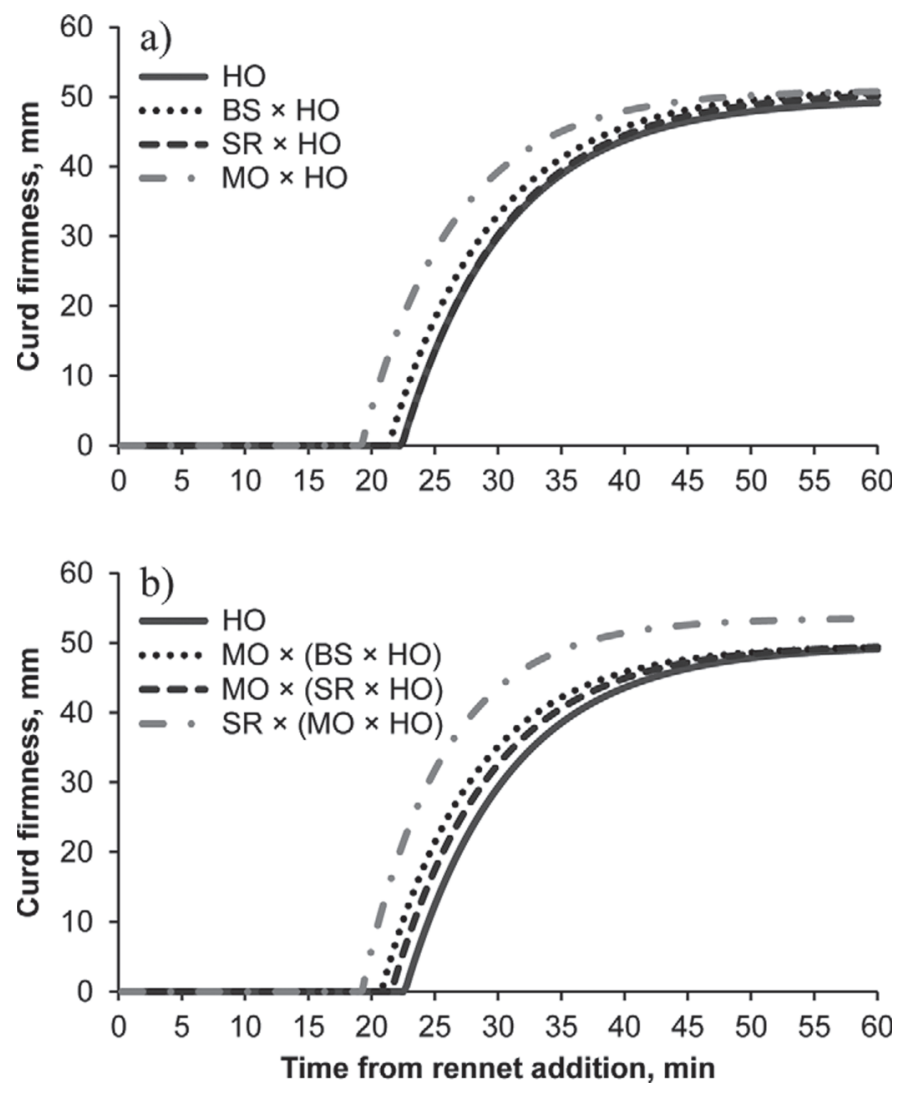

Figure 4. Curd firmness modeling of (a) purebred Holsteins (HO) and first-generation Swedish Red $(\mathrm{SR}) \times \mathrm{HO}$, Montbéliarde $(\mathrm{MO}) \times$ $\mathrm{HO}$, and Brown Swiss $(\mathrm{BS}) \times \mathrm{HO}$ crossbred cows, and of $(\mathrm{b})$ purebred $\mathrm{HO}$ and second-generation $\mathrm{SR} \times(\mathrm{MO} \times \mathrm{HO}), \mathrm{MO} \times(\mathrm{SR} \times \mathrm{HO})$, and $\mathrm{MO} \times(\mathrm{BS} \times \mathrm{HO})$ crossbred cows.

viable method for improving the technological properties of milk, particularly the coagulation time and curdfirming process. Different sire breeds are characterized by specific technological aptitudes that may not be strictly related to other milk quality traits. We herein report that an improvement of milk characteristics (in terms of the quality and technological properties of milk) can be achieved, on average, using crossbreeding of $\mathrm{HO}$ cows with $\mathrm{BS}, \mathrm{MO}$, and SR sires, and that these favorable characteristics can be maintained in the third generation of 3 -way crosses without negative effects on milk yield, despite the further reduction of the $\mathrm{HO}$ heritage from 50 to $25 \%$. These findings suggest that, depending on the intended use of the milk, different types of sires can be chosen to ensure the optimization of farm crossbreeding programs. Then, crossbreeding can contribute, optimizing breed combinations, to improve the entire dairy chain, also of intensive dairy farming systems specialized in the production of PDO hard, long-ripened cheeses, such as Grana Padano and Parmigiano-Reggiano. However, further studies are needed on the genetic and technological bases of the milk properties of different breeds and on the possible maternal/dominance effects of different breed combinations.

\section{ACKNOWLEDGMENTS}

This activity has been developed within the Filigrana Project funded by the Italian Ministry of Agricultural, Food and Forestry Policies (Rome, Italy; MiPAAF D.M. 25741/7303/11 del 1.12.11) within the Food Laboratory, realized under the project "Strengthening of the facilities supporting biotechnology research" of the Veneto Region (Italy; RISIB SMUPR project 4145: Regional competitiveness and job creation; FESR 2007/2013 Action 1.1.1). The authors also thank the technical staff of the Lucio Toniolo Experimental Farm (University of Padova, Legnaro, Italy) for their assistance in data collection, the Genesi Project Srl (Genoa, Italy), and the managers of the 3 dairy farms for their collaboration.

\section{REFERENCES}

Ali, A. K. A., and G. E. Shook. 1980. An optimum transformation for somatic cell concentration in milk. J. Dairy Sci. 63:487-490.

Annibaldi, S., F. Ferri, and R. Morra. 1977. Nuovi orientamenti nella valutazione tecnica del latte: Tipizzazione lattodinamografica. Sci. Tecn. Latt. Cas. 28:115-126.

Auldist, M. J., C. Mullins, B. O'Brien, B. T. O'Kennedy, and T Guinee. 2002. Effect of cow breed on milk coagulation properties. Milchwissenschaft 57:140-143.

Bittante, G. 2011. Modeling rennet coagulation time and curd firmness of milk. J. Dairy Sci. 94:5821-5832.

Bittante, G., A. Cecchinato, N. Cologna, M. Penasa, F. Tiezzi, and M. De Marchi. 2011a. Factors affecting the incidence of first-quality wheels of Trentingrana cheese. J. Dairy Sci. 94:3700-3707.

Bittante, G., C. Cipolat-Gotet, and A. Cecchinato. 2013a. Genetic parameters of different measures of cheese yield and milk nutrient recovery from an individual model cheese-manufacturing process. J. Dairy Sci. 96:7966-7979.

Bittante, G., N. Cologna, A. Cecchinato, M. De Marchi, M. Penasa, F. Tiezzi, I. Endrizzi, and F. Gasperi. 2011b. Monitoring of sensory attributes used in the quality payment system of Trentingrana cheese. J. Dairy Sci. 94:5699-5709.

Bittante, G., B. Contiero, and A. Cecchinato. 2013b. Prolonged observation and modelling of milk coagulation, curd firming, and syneresis. Int. Dairy J. 29:115-123.

Bittante, G., M. Penasa, and A. Cecchinato. 2012. Invited review: Genetics and modeling of milk coagulation properties. J. Dairy Sci. 95:6843-6870.

Blöttner, S., B. J. Heins, M. Wensch-Dorendorf, L. B. Hansen, and H. H. Swalve. 2011. Short communication: A comparison between purebred Holstein and Brown Swiss $\times$ Holstein cows for milk production, somatic cell score, milking speed, and udder measurements in the first 3 lactations. J. Dairy Sci. 94:5212-5216.

Bonfatti, V., A. Cecchinato, L. Gallo, A. Blasco, and P. Carnier. 2011. Genetic analysis of detailed protein composition and coagulation properties in Simmental cattle. J. Dairy Sci. 94:5183-5193.

Bonfatti, V., G. Di Martino, A. Cecchinato, L. Degano, and P. Carnier. 2010. Effect of $\beta$-к-casein (CSN2-CSN3) haplotypes, $\beta$-lactoglobulin (BLG) genotypes, and detailed protein composition and coagulation properties of individual milk of Simmental cows. J. Dairy Sci. 93:3809-3817.

Brandt, G. W., C. C. Brannon, and W. E. Johnston. 1974. Production of milk and milk constituents by Brown Swiss, Holsteins, and their crossbreds. J. Dairy Sci. 57:1388-1393. 
Cecchinato, A. 2013. Survival analysis as a statistical methodology for analyzing factors that affect milk coagulation time in HolsteinFriesian and Brown Swiss cows. J. Dairy Sci. 96:5556-5564.

Cecchinato, A., and P. Carnier. 2011. Short communication: Statistical models for the analysis of coagulation traits using coagulating and non-coagulating milk information. J. Dairy Sci. 94:4214-4219.

Cecchinato, A., C. Cipolat-Gotet, J. Casellas, M. Penasa, A. Rossoni, and G. Bittante. 2013. Genetic analysis of rennet coagulation time, curd-firming rate, and curd firmness assessed over an extended testing period using mechanical and near-infrared instruments. J. Dairy Sci. 96:50-62.

Cecchinato, A., M. De Marchi, L. Gallo, G. Bittante, and P. Carnier. 2009. Mid-infrared spectroscopy predictions as indicator traits in breeding programs for enhanced coagulation properties of milk. J. Dairy Sci. 92:5304-5313.

Cecchinato, A., M. Penasa, M. De Marchi, L. Gallo, G. Bittante, and P. Carnier. 2011. Genetic parameters of coagulation properties, milk yield, quality, and acidity estimated using coagulating and noncoagulating milk information in Brown Swiss and HolsteinFriesian cows. J. Dairy Sci. 94:4205-4213.

Cipolat-Gotet, C., A. Cecchinato, M. De Marchi, and G. Bittante. 2013. Factors affecting variation of different measures of cheese yield and milk nutrients recovery from an individual model cheese manufacturing process. J. Dairy Sci. 96:7952-7965.

Cipolat-Gotet, C., A. Cecchinato, M. De Marchi, M. Penasa, and G. Bittante. 2012. Comparison between mechanical and near-infrared methods for assessing coagulation properties of bovine milk. J. Dairy Sci. 95:6806-6819.

Dechow, C. D., G. W. Rogers, J. B. Cooper, M. I. Phelps, and A. L. Mosholder. 2007. Milk, fat, protein, somatic cell score, and days open among Holstein, Brown Swiss, and their crosses. J. Dairy Sci. 90:3542-3549.

Ferragina, A., C. Cipolat-Gotet, A. Cecchinato, and G. Bittante. 2013. The use of Fourier-transform infrared spectroscopy to predict cheese yield and nutrient recovery or whey loss traits from unprocessed bovine milk samples. J. Dairy Sci. 96:7980-7990.

Hallén, E., T. Allmere, J. Näslund, A. Andrén, and A. Lundén. 2007. Effect of genetic polymorphism of milk proteins on rheology of chymosin-induced milk gels. Int. Dairy J. 17:791-799.

Heins, B. J., and L. B. Hansen. 2012. Short communication: Fertility, somatic cell score, and production of Normande $\times$ Holstein, Montbéliarde $\times$ Holstein, and Scandinavian Red $\times$ Holstein crossbreds versus pure Holsteins during their first 5 lactations. J. Dairy Sci. 95:918-924.

Heins, B. J., L. B. Hansen, and A. J. Seykora. 2006. Production of pure Holsteins versus crossbreds of Holstein with Normande, Montbeliarde, and Scandinavian Red. J. Dairy Sci. 89:2799-2804.

Ikonen, T., K. Ahlfors, R. Kempe, M. Ojala, and O. Ruottinen. 1999 Genetic parameters for the milk coagulation properties and prevalence of noncoagulating milk in Finnish dairy cows. J. Dairy Sci. $82: 205-214$

Ikonen, T., S. Morri, A.-M. Tyrisevä, O. Ruottinen, and M. Ojala. 2004. Genetic and phenotypic correlations between milk coagulation properties, milk production traits, somatic cell count, casein content, and pH of milk. J. Dairy Sci. 87:458-467.

International Dairy Federation. 2012. The world dairy situation. Bulletin 458/2012. International Dairy Federation, Brussels, Belgium.

Jõudu, I., M. Henno, T. Kaart, T. Püssa, and O. Kärt. 2008. The effect of milk protein contents on the rennet coagulation properties of milk from individual dairy cows. Int. Dairy J. 18:964-967.

Kargo, M., P. Madsen, and E. Nordberg. 2012. Short communication: Is crossbreeding only beneficial in herds with low management level? J. Dairy Sci. 95:925-928.

Kreuzer, M., A. M. von Siebenthal, A. Kaufmann, H. Raetzer, E. Jakob, and F. Sutter. 1996. Determination of the relative efficacy to enhance milk renneting properties of alterations in dietary energy, breed and stage of lactation. Milchwissenschaft 51:633-637.

Macciotta, N. P. P., A. Cecchinato, M. Mele, and G. Bittante. 2012. Use of multivariate factor analysis to define new indicator variables for milk composition and coagulation properties in Brown Swiss cows. J. Dairy Sci. 95:7346-7354.
Macheboeuf, D., J.-B. Coulon, and P. D'Hour. 1993. Effect of breed, protein genetic variants and feeding on cows' milk coagulation properties. J. Dairy Res. 60:43-54.

Malacarne, M., A. Summer, E. Fossa, P. Formaggioni, P. Franceschi, M. Pecorari, and P. Mariani. 2006. Composition, coagulation properties and Parmigiano-Reggiano cheese yield of Italian Brown and Italian Friesian herd milks. J. Dairy Res. 73:171-177.

Malchiodi, F., M. Penasa, F. Tiezzi, and G. Bittante. 2011. Milk yield traits, somatic cell score, milking time and age at calving of pure Holstein versus crossbred cows. Agriculturae Conspectus Scientificus 76:259-261.

Malossini, F., S. Bovolenta, C. Piras, M. Dalla Rosa, and W. Ventura. 1996. Effect of diet and breed on milk composition and rennet coagulation properties. Ann. Zootech. 45:29-40.

Martin, B., S. Buchin, and C. Hurtaud. 2003. Conditions de production du lait et qualités sensorielles des fromages. Prod. Anim. $16: 283-288$.

McAllister, A. J. 2002. Is crossbreeding the answer to questions of dairy breed utilization? J. Dairy Sci. 85:2352-2357.

McMahon, D. J., and R. J. Brown. 1984. Enzymic coagulation of casein micelles: A review. J. Dairy Sci. 67:919-929.

McMahon, D. J., G. H. Richardson, and R. J. Brown. 1984. Enzymic milk coagulation: Role of equations involving coagulation time and curd firmness in describing coagulation. J. Dairy Sci. 67:11851193.

Penasa, M., M. Cassandro, D. Pretto, M. De Marchi, A. Comin, S. Chessa, R. Dal Zotto, and G. Bittante. 2010a. Short communication: Influence of composite casein genotypes on additive genetic variation of milk production traits and coagulation properties in Holstein-Friesian cows. J. Dairy Sci. 93:3346-3349.

Penasa, M., M. De Marchi, R. Dal Zotto, G. de Jong, G. Bittante, and M. Cassandro. 2010b. Heterosis effects in a black and white dairy cattle population under different production environments. Livest. Sci. 131:52-57.

Poulsen, N. A., H. P. Bertelsen, H. B. Jensen, F. Gustavsson, M. Glantz, H. Lindmark Månsson, A. Andrén, M. Paulsson, C. Bendixen, A. J. Buitenhuis, and L. B. Larsen. 2013. The occurrence of noncoagulating milk and the association of bovine milk coagulation properties with genetic variants of the caseins in 3 Scandinavian dairy breeds. J. Dairy Sci. 96:4830-4842.

Prendiville, R., K. M. Pierce, and F. Buckley. 2010. A comparison between Holstein-Friesian and Jersey dairy cows and their $\mathrm{F}_{1}$ cross with regard to milk yield, somatic cell score, mastitis, and milking characteristics under grazing conditions. J. Dairy Sci. 93:27412750 .

Saccà, E., S. Bovolenta, W. Ventura, and G. Gaiarin. 2003. Coagulation properties and Nostrano di Primiero cheese yield of milk from Brown grazing cows of different $\kappa$-casein genotype. Ital. J. Anim. Sci. 2(Suppl. 1):284-286.

Summer, A., P. Franceschi, A. Bollini, P. Formaggioni, F. Tosi, and P. Mariani. 2003. Seasonal variations of milk characteristics and cheesemaking losses in the manufacture of Parmigiano-Reggiano cheese. Vet. Res. Commun. 27(Suppl. 1):663-666.

Tyrisevä. A.-M., T. Ikonen, and M. Ojala. 2003. Repeatability estimates for milk coagulation traits and non-coagulation of milk in Finnish Ayrshire cows. J. Dairy Res. 70:91-98.

Tyrisevä, A.-M., T. Vahlsten, O. Ruottinen, and M. Ojala. 2004. Noncoagulation of milk in Finnish Ayrshire and Holstein-Friesian cows and effect of herds on milk coagulation ability. J. Dairy Sci. 87:3958-3966.

Vance, E. R., C. P. Ferris, C. T. Elliot, S. A. McGettrick, and D. J. Kilpatrick. 2012. Food intake, milk production, and tissue changes of Holstein-Friesian and Jersey $\times$ Holstein-Friesian dairy cows within a medium-input grazing system and a high-input total confinement system. J. Dairy Sci. 95:1527-1544.

Weigel, K. A., and K. A. Barlass. 2003. Results of a producer survey regarding crossbreeding on US dairy farms. J. Dairy Sci. $86: 4148-4154$ 